\title{
Editorial \\ Feminisms and the Study of Religion in the 21st Century
}

\author{
Darlene M. Juschka
}

Women's and Gender Studies and Religious Studies Departments, University of Regina, Regina, SK S4S 0A2, Canada; Darlene.Juschka@uregina.ca

Received: 13 November 2018; Accepted: 29 November 2018; Published: 10 December 2018

The articles included in this special issue on feminisms and the study of systems of belief and practice are arranged in three large sections that speak to the general orientation of the papers within the section. Found in section one, "Women's engagement with, and agency within, systems of belief and practice", are Reid Leamaster and Andres Bautista's case study of Mormon women's intersection with the gender ideology of their system of belief and practice, and Ann Hege Grung's 2014 study of Lebanese domestic violence laws and their reception by NGOs and religious leaders. Chia Longman's contribution is an ethnographic study of primarily white middle-class groups of feminist women in Belgium, Germany and the Netherlands who create and participate in a "womanly space" that includes spiritual well-being, while Melissa Wilde and Hajer Al-Faham's contribution looks at how US religious organizations responded to women's reproductive choice in the form of access to birth control between 1929 and 1965. All of the papers locate the social group women at the center of their analysis examining the various ways humans marked as female/feminine are constituted by gender ideological systems deployed within (and without) systems of belief and practice.

Section two, "Feminism theory/praxis deployed," includes five contributions beginning with Catherine Robinson and Denise Cush's reflections of feminist praxis and pedagogy in the study of religion and religious education in the United Kingdom. They argue for the inclusion of feminist pedagogy as it requires "Religious Studies and Religious Education to rethink their content, methods and aims", while Nathan Eric Dickman provides a reading of the philosophy of religion hoping to elucidate a "philosophy of religions renewed through feminisms-moving from fringe to normative topics in institutionalized philosophy of religion ... ". Verna Marina Ehret's narrative analysis asks what feminists can learn from anti-feminist and masculinist narratives that take feminism narratives to be a threat or threatening, while Gail Turely Houston engages in an in-depth study of the life of the feminist suffragette Eliza Sharpe and her efforts to formulate a feminist spirituality in the early days of feminism in the UK. The last piece in this section written by Amy Paris Langenberg draws on case study reports to examine female monastics' responses and challenges to a conservative gender ideology.

Section three, "The play of gender", shifts to the subject of gender with regard to systems of belief and practice. Play, or the deployment, imperatives, and outcomes, within social systems is a term used in critical theory that points to the instability of gender and its doing, that is its performance, a performance, following Judith Butler, of "presence and absence on the body's surface" (Butler 1999, p. 172). Colette Harris opens this section with an examination of the use and imposition of colonial gender ideology through the early 20th century conversion attempts of the Anglican (and Catholic) Church on the Acholi people of Uganda. Following Harris is Lisa Weaver Swartz's enthnographic study situted in the Asbury Theological Seminary wherein she compares liberal, secular feminist views of women with what she argues is a normative Wesleyan egalitarian view of women. In her contribution Roxana Baiasu locates side by side the work of feminist philosophers in the study of systems of belief and practice and Wittgensteinian post-metaphysical approaches in order to think 
about the "ineffable" particularly in light of feminists' insistence that all knowledge is situated (Harding 2006), while Laura Zwissler's engaging piece on the dichotomy between magic and religion, with the former associated with the female/feminine in the figure of the witch, asks what do scholars of religion miss when we dismiss the activities of those others not worthy of consideration? How thorough, comprehensive and viable are our studies and what does it mean to miss more than half the population when androcentric scholars continue to locate, and therefore legitimate, the Subject, "man", and "his" encounters with existence?

Conflicts of Interest: The author declares no conflict of interest.

\section{References}

Butler, Judith. 1999. Gender Trouble: Feminism and the Subversion of Identity. New York and London: Routledge. Harding, Sandra. 2006. Science and Social Inequality: Feminist and Postcolonial Issues. Race and Gender in Science Studies. Urbana: University of Illinois Press.

(C) 2018 by the author. Licensee MDPI, Basel, Switzerland. This article is an open access article distributed under the terms and conditions of the Creative Commons Attribution (CC BY) license (http://creativecommons.org/licenses/by/4.0/). 